\title{
Højskole og sport - om idrætten i Vejen
}

af lektor, lic.phil. Niels Kayser Nielsen, Odense Universitet

Det hører til én af den danske idrætshistoriske forsknings kæreste myter, at der historisk set skulle være et modsætningsforhold mellem højskolebevægelsen og sporten, og at dette modsætningsforhold blev etableret allerede i slutningen af forrige århundrede, da højskolebevægelsen introducerede den svenske Ling-gymnastik som sin foretrukne idrætsform, og byborgerskabet og arbejderklassen samtidig sluttede op omkring den nye sport, som blev importeret fra England. Denne modsætning skulle være baseret dels på eksterne forhold som politik og kultur, dels på idrætsinterne forhold, idet gymnastikken hævdedes at lægge vægt på harmoni og skønhed, medens sporten betonede vækst, præstation og konkurrence1).

Synspunktet blev med kraft fremført i Ove Korsgaards oversigtsværk Kampen om kroppen fra 1982, men bygger i øvrigt på en solid grundtvigianisk selvforståelse, der som led i sin egen gårdmandshistorieskrivning også på idrættens område har søgt at holde afstand til lignende bevægelser i samtiden for at tegne sin egen selvstændige profil.

Trods kritik af denne idrætshistoriske gårdmandslinje2) og påpegning af, at også højskolegymnastikken var led i et rationalistisk og modernistisk oplysningsprojekt 3 ), nyder synspunktet fortsat fremme.

At Korsgaard i sin bog konsekvent gennemfører sit synspunkt skyldes antageligt, at han i meget ringe udstrækning har foretaget lokalhistoriske nedslag og stort set bevæger sig på et synteseplan. Der kan derfor være grund til at inddrage lokalhistoriske undersøgelser af idrættens historie, der ikke kun anskuer idrætten organisationshistorisk, men også ser på idrættens social- og kulturhistorie - i lokalt perspektiv. Herom ved vi endnu kun ganske 
lidt i Danmark, hvilket formodentlig må tilskrives den idrætshistoriske forsknings unge alder. Det følgende er et forsøg på i mini-format at råde bod herpå, ligesom det er et forsøg på at problematisere Korsgaards modstilling mellem højskolebevægelse og sport.

\section{Industri og højskolemiljø}

At idrætten allerede omkring 1900 var en del af det omgivende samfund er ikke mindst tydelig i den driftige stationsby Vejen midt i Sydjylland. Beliggende på banelinjen mellem Kolding og Esbjerg udviklede der sig her tidligt en om-fattende industri med en tilhørende befolkningsvækst fra 657 i 1890 til 2829 i 19214), ligesom den grundtvigianske højskolebevægelse her havde sin højborg Askov, beliggende et par kilometer sydvest for Vejen. Mellem disse to miljøer herskede der imidlertid ikke et modsætningsforhold, men tværtimod en ganske tæt og intim relation, baseret på gensidig sympati. Begge miljøer blev ledet af hver sin stærke og magtfulde "konge". På Askov herskede forstander Ludvig Schrøder, i Vejens industrimiljø sad fabrikant Johannes Lauridsen på tronen. Begge disse to mænd var driftige og energiske ledere med udsyn og visioner, og begge var interesserede i såvel den åndelige som den timelige verden.

Forstander Schrøder er undertiden blevet fremstillet som en lidt distræt og verdensfjern højskolemand med hang til vidtløftigheder. Imidlertid var han også en uhyre praktisk tænkende mand, der fuldt ud forstod sig på materialitet og bondepraktik. Da Schrøder og hans hustru i 1887 kunne fejre sølvbryllup, betænkte deres venner ægteparret med en større pengegave. Den ville Schrøder, til stor forargelse for børnene, have brugt til en ajletønde på sin gård; dog sørgede den magtfulde fru Schrøder for, at der også kunne blive råd til et sølvskab5). I det hele taget gik Schrøder med liv og sjæl op i sit landbrug på Damgaarden, ikke mindst kvægbruget. Han havdenogle meget fine køer på sin gård. Den fineste, der blev stammoder til en hel familie, hed "Gl. Gram". Skelettet af den blev senere opstillet på Ladelund Landbrugsskole til gavn for anatomiundervisningen, og det fortælles, at på Konrad Jørgensens trykkeri i Kolding, hvor bl.a. Højskolebladet blev trykt, var de to mest brugte klicheer billederne af Grundtvig og Gram. Ligeledes kom Schrøder i nært forhold til C. F. Tietgen og benyttede oftelejligheden til at berømme ham over for eleverne på Askov6). 
Tilsvarende var Johannes Lauridsen på gården Grønvang ikke kun en åndløs kapitalist. Han deltog aktivt i Vejen sociale og kulturelle liv. Og den opvakte og vidt foregrenede Lauridsen-familie var blandt medstifterne af Dansk Højskoleforening i 18787), ligesom familien tilhørte kredsen af Askov Højskoles nærmeste venner. Således var det Poul la Cour på Askov - et af medlemmerne af den berømte "Norrlander-tylvt", der havde været med til at introducere den svenske gymnastik i Danmark - som havde navngivet Johs. Lauridsens margarinefabrik Alfa ${ }^{8}$ ). I bestyrelsen herfor sad udover J. Lauridsen dennes broder, købmand Peter Lauridsen, justitsråd C.H. Clausen, Holsted, apoteker N.C. Müller, Kolding, samt Paul la Cour. Udover margarine-fabrikken 'sad' Lauridsen på tagpapfabrikken Phønix, hvis første direktør i 1909 blev sønnen Olav Vang Lauridsen9), ligesom han allerede i 1878 havde startet Cikorietørreriet, som ved siden af teglværkerne var Vejens ældste industrivirksomhed ${ }^{10}$ ). Han havde desuden en finger med i spillet $\mathrm{i}$ både mejeriet og svineslagteriet, idet han i begge tilfælde var formand for bestyrelsen, ligeledes havde han startet en såkaldt "engforening", der satsede på dambrug. Johannes Lauridsen var desuden interesseret $i$ byens forskønnelse og rekreative forbedring og var således formand for det konsortium, der havde opkøbt en landejendom med henblik på at skabe et anlæg11). Endelig var han også interesseret i idrætssagen. Han havde været blandt lederne i skytte- og gymnastikforeningen i Vejen ${ }^{12)}$, og der er grund til at tro, at han har støttet, at man fra Vejen i 1885 lod snedkersvend Laurids Vig sende til Lund for at deltage i det kursus, som kaptajn Norrlander dér lod holde for 12 danske deltagere. Udover Laurids Vig indgik heri også Poul la Cour fra Askov, der blev "Norrlander-tylvtens" åndelige leder.

Hvorfra Johannes Lauridsen har hentet denne idrætsinteresse ved vi ikke. Måske fra sin broder Jeppe Lauridsen, der var en ivrig bryder og som en gang i sin ungdom i Vejen havde besejret en tysk bryder og cirkusdirektør, og som senere ved en stor gymnastikfest for hele landet i Nyborg i 1880 havde kastet en stor og stærk skorstensfejer fra Odense ${ }^{13}$ ).

\section{Sportens opkomst i Vejen}

Da Vejen Sportsforening i 1890 indleder sine aktiviteter, er hovedmændene bag initiativet henholdsvis privatlærer Hans Birkelund, som underviste på gården Grønvang, dvs. hos Johannes Lauridsen og Olivarius Jürgensen14), 
som var kommis hos købmand Peter Lauridsen, Johs. Lauridsens broder, som ligeledes havde forbindelse til højskolen. Askov Højskole var på daværende tidspunkt inde i en idrætslig frugtbar gæringsperiode, hvor den dynamiske Ingeborg Schrøder, uden korset og i fri reform-gymnastikdragt, fra sommeren 1889 havde overtaget undervisningen i kvindelig gymnastik og sundhedslære, og hvor hendes tilkommende Jacob Appel, den senere undervisningsminister, i 1890 blev tilbudt en lærerstilling - omend han var meget lidt glad for at se Ingeborg i reformdragt. Men samtidig havde man årene inden været inde i en økonomisk vanskelig periode, hvor skolen havde svært ved at holde sig oven vande, fordi elevtallet var vigende og lærerlønningerne var stigende. Det er ind i et sådant miljø, sporten i Vejen træder sine barnesko.

I en dagbog fra $1890 \mathrm{og}$ frem kan man se, at der fra starten var tætte forbindelser til familien Lauridsen, som altid havde været delagtig i højskolebevægelsen. Vejen Sportsforening havde på dette tidspunkt, i december 1890, udelukkende fodbold på programmet. Fem år senere kan man af referatet fra en ekstraordinær generalforsamling se, at lærer Birkelunds afløser som huslærer på Grønvang indvælges i bestyrelsen for Sportsforeningen ${ }^{15)}$, hvilket atter bekræfter forbindelsen mellem højskolemiljøet, Lauridsens og sportsforeningen. Familien Lauridsen skulle igen og igen vise sig at være til uvurderlig hjælp for sporten i Vejen

Allerede april 1899 forhandlede sportsforeningen med fabrikant Johs. Lauridsen om en spilleplads ved fabriksanlægget, som blev bevilget mod en lejepris på $30 \mathrm{kr}$. for sommeren 189916). Det skete året efter, at han bekostede omdannelsen af det gamle biblioteksrum på Askov Højskole til et styrtebadsrum ${ }^{17)}$. I 1902 køber Sportsforeningen egen bane ved Nørregade. Man betaler $1362 \mathrm{kr}$. for 2 tønder land jord plus $250 \mathrm{kr}$. for en adgangsvej gennem landpost Petersens have. Til gengæld tilbyder sognerådet at overtage arealet og garantere eller udbetale resten af købesummen, dog ikke over 1000 kr., mod at idrætsforeningen som modydelse for brugsretten afdrager og forrenter disse penge, og mod at kommunens skolesøgende børn har adgang til baneanlægget ${ }^{18)}$. Formanden for sognerådet var Johs. Lauridsen.

Men også på den aktive front tager familien Lauridsen del i idrætslivet $\mathrm{i}$ Vejen. År 1900, da Vejen på Alfa-anlægget for første gang spiller mod et københavnerhold, B93, er J. Lauridsens søn Olav Vang Lauridsen målmand på holdet, ligesom en anden søn spiller back på fodboldholdet i 1907. En 


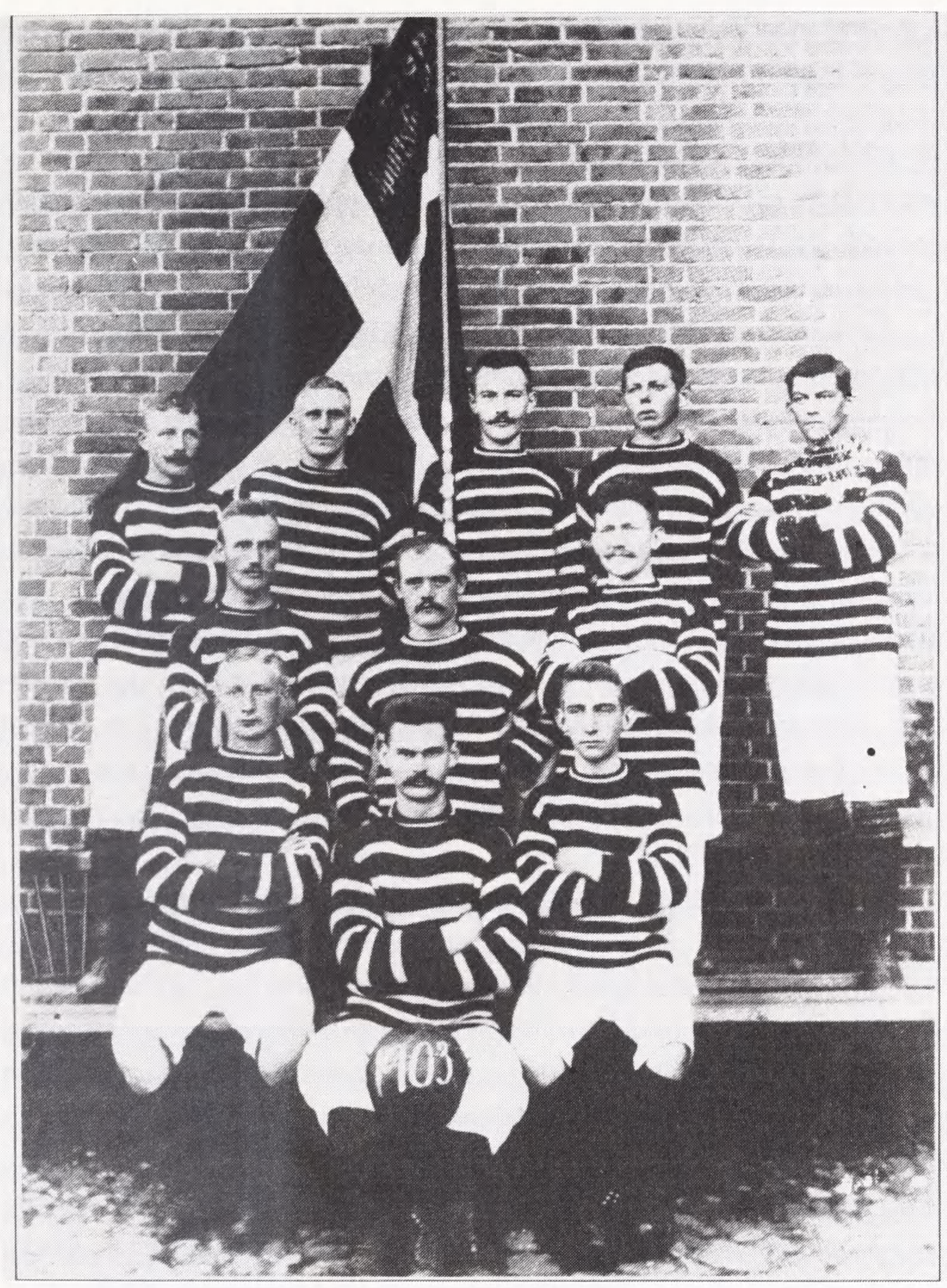

1903: Vinder af mesterskabsturneringen arrangeret af Fællesforeningen af Jyske Idrætsklubber. Fra Vejen Sportsforening gennem 100 år, 1990.

modsætning mellem højskoleverden og sportsverden kan man vanskeligt få øje på: året efter, at Olav Vang Lauridsen står på mål for fodboldholdet, tager han om vinteren på Testrup Højskole ${ }^{19)}$, hvor den kendte skyttesag- og 
gymnastikmand J. Nørregaard var forstander. Og det skulle ikke blive sidste gang, at familien Lauridsen trådte hjælpende til overfor sporten i Vejen.

\section{Sport i Vejen i mellemkrigstiden}

Sport i Vejen er i mellemkrigstiden så godt som udelukkende ensbetydende med fodbold. Det er desuden i denne periode, især i 1930'erne, at stationsbyholdet gør sig gældende blandt landets førende hold. Og det er i denne periode udtrykket de "jyske skotter" vinder udbredelse, idet det hed sig, at Vejen spillede lige så godt som de dengang så berømte skotske fodboldspillere. Klubben spillede igennem det meste af tiden i den jyske mesterrække, som man vandt $i$ både 1935-36 og 1936-37, således at klubben her blev jysk mester foran så stærke klubber som AGF, Esbjerg fB og Vejle. Det betød, at man efter sæsonen 1936-37 rykkede op i 1. division, der nu var landsdækkende, da DBU havde lavet en ny turneringsordning i 1936. Vejens oprykning kom således på et belejligt tidspunkt og vakte stor interesse, ikke mindst i København, hvor mange tilskuere ville i Idrætsparken for at se det jyske "bondehold". Til en kamp mod AB fik man $7.000 \mathrm{kr}$. med hjem til Vejen som følge af tilskuertilstrømningen.Til gengæld spærrede krigen for klubbens videre succes på landsplan, idet man i besættelsesårene suspenderede den landsdækkende turnering.

Ikke desto mindre var der tale om en yderst bemærkelsesværdig præstation. Grundene hertil er givetvis mange, men blandt de væsentligste må man pege på en utrolig lokal opbakning bag klubben, hvis lige man nok skal til GOG på Sydfyn for at finde en nutidig pendant til. I Vejens første landsholdsspiller, Thorvald Schultz' erindringer Fra mange Aars Fodboldliv fra 1924 kan man læse, at denne stationsby med dens ca. 3.000 indbyggere er "gennemsyret af sport"20).

En anden forklaring er det svært bestemmelige, men sportsligt yderst vigtige begreb "fodboldkultur": gennem årenehavde mani Vejen skabten særlig teknisk spillestil, der år efter år kendetegnede alle klubbens hold, således at nyoprykkede ungdomsspillere fra starten var fortrolig med måden, hvorpå der skulle spilles på eliteplan. Desuden må man pege på, at klubben i begyndelsen af 1920'erne var fremsynet nok til at skaffe sig trænere, endda dygtige trænere. Noget sådant var ellers ikke almindeligt. Den første man engagerede var den tidligere landsholdsmålmand Sophus Hansen, der 
måske nok ikke kunne lære spillerne så meget nyt, men til gengæld fik dem bragt i kanonform, således at var i bedste træningstilstand. Også Sophus "Krølben" Nielsen, der også blev landsholdstræner, var igennem flere perioder ansat i Vejen. Størst succes havde imidlertid ungareren Fritz Molnar, der lagde grunden til den kendte, tekniske Vejen-stil.

Endelig kan man ikke se bort fra Vejens erhvervslivs opbakning bag klubben. Her var det i særdeleshed Olav Vang Lauridsen fra margarinefabrikken Alfa, som var klubben yderst venligt stemt. Således var det ham, der i 1931 gratis tildelte klubben 2,5 tønde land jord som areal ved opførelsen af det nye stadion, som skulle afløse det gamle Nørregade-anlæg fra 190221), som faderen qua sognerådsformand havde skaffet idrætten på yderst favorable vilkår. I en tid med massearbejdsløshed som i trediverne var det også et aktiv for klubben, at man som arbejdsløs fodboldspiller kunne få arbejde på Alfa. Det er forkert at tale om professionelle tilstande $\dot{r}$ Vejen, og klubben var ikke et rent firmahold, men fremgangsmåden, at Vang Lauridsen skaffede arbejde på sin fabrik, blev benyttet $i$ adskillige tilfælde ${ }^{22}$ ). Flere af klubbens kendteste spillere i 1930'erne kom således udefra. Et sådant system var ganske udbredt i mellemkrigstiden, blot var det ekstraordinært tydeligt $\mathrm{i}$ Vejen. Det var ulempen ved at være en lille klub med stor succes, men det var på den anden side også en forlængelse af den tradition, som Johs. Lauridsen med udgangspunkt $\mathrm{i}$ højskoleidrætten havde etableret omkring århundredskiftet 1900.

\section{Orgel, sport og håndbibliotek}

Historien om idrætten i Vejen fortæller, at den traditionelle modstilling mellem gymnastik, højskole og præstationsundsigelse på den ene side og sport, idrætsforening og præstation på den anden side er alt for firkantet. Højskolerne og deres idræt var i høj grad en del af den samlede modernisering af bonde-Danmark og var i tilsvarende høj grad inferesserede i vækst, produktivitet, konkurrence, præstation og dermed sport, ligesom den sportive del af Danmark i regi af Dansk Idræts Forbund fra starten tog Niels Bukhs højskole-gymnastik til sit hjerte. Når man ser på idrættens historie på lokalt plan, udviskes den så firkantet-ideologiske skelnen mellem højskoleidræt og sport yderligere. Det viser bl.a. historien om idrætten i Vejen, som via familien Lauridsen fra sin start er intimt forbundet med højskolernes 
højborg i Askov. Fællesnævneren var modernisering og folkeoplysning. Det er således helt i overensstemmelse med Lauridsen-familiens generelle opfattelse, at Maren Lauridsen på Grønvang i 1909 donerer et nyt orgel til den nye Vejen kirke23), og at grosserer P. Lauridsen i 1915 tilbyder Vejen by et håndbibliotek på 2000 bind samt inventar til de nødvendige lokaler, mod at kommunen garanterer, at biblioteket altid er tilgængeligt i gode og hyggelige omgivelser ${ }^{24)}$. Det sker samtidig med, at familien Lauridsen både aktivt og passivt slutter op om sporten i idrætsforeningen.

Noter

1) Ove Korsgaard: Kampen om kroppen. Dansk idræts historie gennem 200 år. Kbh. 1982, passim. Se især s. $164 \mathrm{ff}$.

2) Jvf. Niels Kayser Nielsen: Et overset kapitel - om sporten og gårdmandslinjen i dansk idrætshistorie, i: Else Trangbæk (red.): Den engelske sports gennembrud i Norden. Kbh. 1990, s. 173 ff.

3) Jvf. Niels Kayser Nielsen: Krop og oplysning. Om kropskulturi Danmark17801900. Odense 1993.

4) Jvf. Olav Vang Lauridsen og Jens Peter Harbo(red.): Slægten Lauridsen på Grønvang, Vejen og nogle af dens slægtsforbindelser. Vejen 1921, s. 162.

5) Jvf. Hans Lund: Askov Højskole 18651915. Kbh. 1965, s. 260.

6) Jvf. Note 5), s 262.

7) Jvf. Note 4), s. 431.

8) Jvf. Note 4), s. 153.

9) Jvf. Note 4), s. 200.

10) Jvf. Søren Alkærsig: Vejen Sogn i Malt Herred, bd. 2. Vejen 1940, s. 350 f.

11) Jvf. Note 4), s. 161.

12) Jvf. Note 10), s. 447.

13) Jvf. Note 4), s. $216 \mathrm{f}$.

14) Jvf. Leif Christensen: Vejen Sportsforening gennem 100 år. Vejen 1990, s. 13.

15) Jvf. Note 14), s. 19.

16) Jvf. Note 14), s. 20.

17) Jvf. Hans Lund: Askov Højskole 18651915. Kbhvn. 1965, s. 252.

18) Jvf. Note 10), s. 415.

19) Jvf. Note 4), s. 199.

20) Her citeret fra Leif Christensen: Vejen Sportsforening gennem 100 år. Vejen 1990, s. 29.

21) Jvf. Note 20), s. 45.

22) Jvf. Note 20), s. 36.

23) Jvf. Note 10), s. 475.

24) Jvf. Note 10), s. 453. 